\title{
Effects of heat treatment and storage temperature on the use of açaí drink by nutraceutical and beverage industries
}

\author{
Efeito do tratamento térmico e da temperatura de armazenamento na aplicação da bebida de açaí pelas \\ indústrias nutraceuticas e de bebidas
}

\author{
Tatiane Regina ALBARICI ${ }^{1}$, José Dalton Cruz PESSOA ${ }^{1 *}$
}

\begin{abstract}
This study assesses the storage temperature effect on the anthocyanins of pasteurized and unpasteurized açaí pulp. The data was obtained using a pasteurized and lyophilized pulp (PLP) to evaluate the temperature effect $\left(0,25\right.$, and $\left.40{ }^{\circ} \mathrm{C}\right)$. Part of non-pasteurized frozen pulp (NPP) was pasteurized (NPP-P) at $90^{\circ} \mathrm{C}$ for 30 seconds; both pulps were stored at $40^{\circ} \mathrm{C}$. The anthocyanin content reduction in the drink was evaluated from the half-life time $\left(\mathrm{t}_{1 / 2}\right)$, activation energy $(\mathrm{Ea})$, temperature quotient $(\mathrm{Q} 10)$, and the reaction rate constant $(\mathrm{k})$. The $\mathrm{t}_{1 / 2}$ of the PLP anthocyanins stored at $40{ }^{\circ} \mathrm{C}$ was 1.8 times less than that stored at $25^{\circ} \mathrm{C}$ and 15 times less than that stored at $0{ }^{\circ} \mathrm{C}$; therefore, the higher temperatures decreased the stability of anthocyanins. The pasteurization increased the $t_{1 / 2}$ by 6.6 times $(10.14$ hours for NPP and 67.28 hours for NPP-P). The anthocyanin degradation on NPP-P followed a first order kinetic, while NPP followed a second order kinetic; thus it can be said that the pasteurization process can improve the preservation of anthocyanins in the pulp.

Keywords: Euterpe oleracea; açaí pulp; anthocyanins; degradation; pasteurization.
\end{abstract}

\begin{abstract}
Resumo
Este trabalho avaliou o efeito da temperatura de armazenamento nas antocianinas de polpas de açaí pasteurizadas e não pasteurizadas. Para avaliar o efeito da temperatura $\left(0,25\right.$ e $\left.40{ }^{\circ} \mathrm{C}\right)$, os dados foram obtidos usando a polpa pasteurizada e liofilizada (PLP). Uma parte da polpa não pasteurizada e congelada (NPP) foi pasteurizada (NPP-P) a $90^{\circ} \mathrm{C}$ por 30 segundos e ambas foram armazenadas a $40{ }^{\circ} \mathrm{C}$. A redução das antocianinas totais na bebida foi avaliada pelo tempo de meia-vida $\left(\mathrm{t}_{1 / 2}\right)$, energia de ativação (Ea), quociente de temperatura (Q10) e constante de velocidade da reação (k). O $t_{1 / 2}$ das antocianinas da PLP armazenada a $40^{\circ} \mathrm{C}$ é 1,8 vezes menor que da armazenada $25^{\circ} \mathrm{C}$ e 15 vezes menor que a $0^{\circ} \mathrm{C}$, portanto quanto maior a temperatura menor a estabilidade das antocianinas. A pasteurização aumentou $\mathrm{t}_{1 / 2} 6,6$ vezes $(10,14$ horas para NPP e 67,28 horas para NPP-P).A degradação das antocianinas na NPP-P seguiu uma cinética de primeira ordem, enquanto NPP seguiu a cinética de segunda ordem, portanto o processo de pasteurização pode aumentar a preservação das antocianinas.

Palavras-chave: Euterpe oleracea; polpa de açaí; antocianinas; degradação; pasteurização.
\end{abstract}

\section{Introduction}

Açai is an important commercial fruit produced in the northeastern region of Pará state, Brazil. In 2002, it represented $66 \%$ of all fruit production and increased to $76 \%$ in the following year (COSTA; ANDRADE; SILVA, 2004). The Secretary of Agriculture of the State of Pará estimated that the açai production in 2004 was of 350 thousand tons of fruits, $35 \%$ more than in 2003. The exports of the frozen drink to the United States and Italy began in 2000. It is estimated that around 2.12 million U.S. dollars were commercialized in 2003, and in 2005 the amount was at least 5.49 million U.S. dollars (SANTANA, 2006). In 2007, the export of fruit juices and pulps in the state of Pará generated the revenue of 17 million USD, of which $60 \%$ was generated by açaí (PARÁ, 2009)

The coarse açaí beverage is obtained by the primary industry that depulps the fruit, sieves, homogenizes, pasteurizes, and freezes the beverage. This drink is rich in fibers and contains proteins, vitamins, macronutrients ( $\mathrm{S}$ and $\mathrm{P})$, and numerous micronutrients ( $\mathrm{Na}, \mathrm{K}, \mathrm{Zn}, \mathrm{Fe}, \mathrm{Mg}$, and $\mathrm{Cu}$ ) (DEL POZOINSFRAN; BRENES; TALCOTT, 2004; GALLORI et al., 2004; IADEROZA et al., 1992; ROGEZ, 2000). The drink also contains polyphenols, some of which are responsible for the attractive reddish blue coloring in the fruits, flowers, and leaves. They also contribute to the antioxidant activity of açaí. This class includes the anthocyanins, a phenolic radical associated with a sugar molecule, which, when dissociated from sugar, is called anthocyanidin (BRIDLE; TIMBERLAKE, 1997). Therefore, the anthocyanins reduce the free radicals, which when in excess cause cardiovascular diseases, inflammation, and skin diseases caused by solar radiation. Free radicals are also associated with neurodegenerative diseases such as Alzheimer and Parkinson diseases (RICE-EVANS, 1999).

\footnotetext{
Received 2/7/2009

Accepted 3/11/2010 (004293)

${ }^{1}$ Empresa Brasileira de Pesquisa Agropecuária - EMBRAPA, Instrumentação Agropecuária, Rua XV de Novembro, 1452, CEP 13560-970, São Carlos, São Paulo, Brazil, e-mail: dalton@cnpdia.embrapa.br

${ }^{*}$ Corresponding author
}

DOI: http://dx.doi.org/10.1590/S0101-20612012005000026 
Recent publications have demonstrated that the consumption of açai juice or pulp increases the plasma antioxidant capacity by 2.3 and 3 times, respectively, in healthy human volunteers (MERTENS-TALCOTT et al., 2008). Other beneficial outcomes attributed to açai pulp are vasodilation effects (ROCHA et al., 2007) and its ciclooxygenase inhibition (COX-1 and COX-2), thus indicating a great anti-inflammatory potential (SCHAUSS et al., 2006). Del Pozo-Insfran, Talcott and Percival (2006) studied the effect of açaí polyphenolic fraction in HL-60 human leukemia cells, and these fractions decreased the cellular proliferation from 56 to $86 \%$. Anthocyanins are thermo-sensitive in solution and plants. These were evaluated in purple cabbage (WALKOWIAK-TOMCZAK; CZAPSK, 2007), purple and red-flesh potatoes (REYES; CISNEROS-ZEVALLOS, 2007), plums (RAYNAL; MOUNTOUNET, 1989), black carrots (KIRCA; OZKAN; CEMEROGLU, 2006; 2007), blackberries (WANG; XU, 2007), raspberries (OCHOA et al., 1999), strawberries, and onions (SÁ; SERENO, 1999). Many of these papers describe that the degradation of anthocyanins follows a first order reaction kinetic (KIRCA; OZKAN; CEMEROGLU, 2006, 2007; REYES; CISNEROS-ZEVALLOS, 2007), except for strawberries, which followed a second order reaction kinetic (SÁ; SERENO, 1999). In all cases, the temperature rise causes an increase in the reaction rate.

The anthocyanins from flowers and fruits can be analyzed by spectrophotometry, which shows reliable results even when compared to chromatography (FULEKI; FRANCIS, 1968; MARÇO, 2005; MALACRIDA; MOTTA, 2005; MOTA, 2006; RAPISARDA; FANELLA; MACARONE, 2000). The spectrometric $\mathrm{pH}$ differential method (AOAC method 2005.02), approved by the Association of Analytical Communities, AOAC International, is based on the reversible structural changes of anthocyanins at $\mathrm{pH} 1.0$ and $\mathrm{pH} 4.5$, in which the absorbance difference at maximum visible wavelengths is proportional to the concentration of the pigment (LEE; DURST; WROLSTAD, 2005; LEE; RENNAKER; WROLSTAD, 2008; GIUSTI; WROLSTAD, 2001).

The presence of anthocyanins in food is related to color and health-promoting components. The first is a desirable aesthetic quality that is attractive to the consumer, and their nutraceutical properties provide a strong marketing argument. This paper analyzes the temperature effect on the availability of anthocyanins in the natural $\mathrm{pH}$ coarse drink.

\section{Materials and methods}

\subsection{Samples}

All samples were processed by Amazonfrut - Frutas da Amazônia Ltda, located in Belém (state of Pará, Brazil). The methodology used herein is the same used for pulp export. The company outsourced the pasteurization and lyophilization of part of the pulp. The pasteurized and lyophilized pulp (PLP) and the frozen non-pasteurized pulp (NPP) were shipped to Embrapa Instrumentação Agropecuária, located in São Carlos, (São Paulo, Brazil).
The NPP was divided into two parts. One part was thawed and pasteurized at $90{ }^{\circ} \mathrm{C}$ for 30 seconds in a $100 \mathrm{~mL}$ stainless container of dimension $20 \times 5 \times 1 \mathrm{~cm}$. After 30 seconds, this sample was cooled and frozen at $-18{ }^{\circ} \mathrm{C}$ until assayed (NPP-P). The other part was kept frozen until assayed (NPP).

\subsection{Temperature influence}

The PLP was reconstituted $(15 \mathrm{~g}$ and $300 \mathrm{~mL}$ of distilled water) and stirred using a magnetic stirrer. After 30 minutes, the juice was strained, added to a $500 \mathrm{~mL}$ volumetric flask, and made up to $500 \mathrm{~mL}$ with distilled water. An aliquot was analyzed to determine the initial anthocyanin contents. The juice was divided into three equal portions and stored in capped flasks. Each flask was stored at a different temperature: an ice bath $\left(0{ }^{\circ} \mathrm{C}\right)$; ambient temperature $\left(25^{\circ} \mathrm{C}\right)$, and thermostatic bath $\left(40^{\circ} \mathrm{C}\right)$. The aliquots were regularly collected in test tubes and immediately cooled in an ice bath until analysis. The total anthocyanin content was evaluated using the $\mathrm{pH}$ differential method (GIUSTI; WROLSTAD, 2001).

\subsection{Pasteurization influence}

A $10 \mathrm{~mL}$ aliquot of NPP and another one of NPP-P were added to two $50 \mathrm{~mL}$ volumetric flasks, made up to $50 \mathrm{~mL}$ with distilled water, and stirred using a magnetic stirrer. After 15 minutes, the juices were filtered. An aliquot of each sample was analyzed to determine the initial anthocyanin content.

The juice was divided into two equal portions and stored in capped flasks in a thermostatic bath at $40{ }^{\circ} \mathrm{C}$. The aliquots were regularly collected in test tubes and immediately cooled in an ice bath until analysis. The total anthocyanin content was evaluated using the pH-differential method (GIUSTI; WROLSTAD, 2001).

\subsection{Anthocyanin content determination using the pH-differential method}

The total anthocyanin content was evaluated using the $\mathrm{pH}$-differential method as described by Giusti and Wrolstad (2001), in which the absorbance difference at $\mathrm{pH} 1.0$ and $\mathrm{pH} 4.5$ is directly proportional to anthocyanin concentrations. The calculation was based on the cyanidin-3-glucoside.

For each sample, $2 \mathrm{~mL}$ aliquots were added to two $10 \mathrm{~mL}$ volumetric flasks. The first one was made up to $10 \mathrm{~mL}$ with potassium chloride buffer $(0.025 \mathrm{M}), \mathrm{pH} 1.0$, and the second one was made up to $10 \mathrm{~mL}$ with sodium acetate buffer $(0.4 \mathrm{M})$, $\mathrm{pH}$ 4.5. The flasks were protected from light using aluminum foil and were left to equilibrate for 30 minutes. After equilibration, absorbance in the 400 to $800 \mathrm{~nm}$ range was read in a Shimadzu UV-1601PC UV-Vis spectrophotometer against water blanks. The anthocyanin content was calculated using Equation 1 as follows:

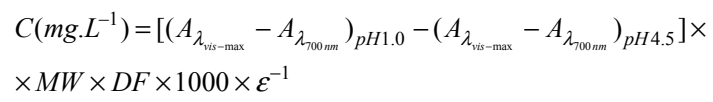

where: $C$ is the anthocyanin content in mg. $\mathrm{L}^{-1} ; A \lambda_{\text {vis-max }}$ is the absorbance at maximum wavelength in the visible region; $A \lambda_{700 \mathrm{~nm}}$ is the absorbance at $700 \mathrm{~nm} ; M W$ is the molecular weight 
of cyanidin-3-glucoside 449.2 g.mol ${ }^{-1} ; D F$ is the dilution factor; $\varepsilon$ is the molar absorptivity of cyanidin-3-glucoside 26,900 .

The dilution factor is calculated dividing the final volume after the addition of buffer $(10 \mathrm{~mL})$ by the volume of the sample $(2 \mathrm{~mL})$; thus, the DF is 5 . The maximum absorbance wavelength $\left(A \lambda_{\text {vis-max }}\right)$ is measured by adding potassium chloride buffer $\mathrm{pH} 1.0$ to the sample and reading the absorbance in the range 400 to $800 \mathrm{~nm}$.

\subsection{Kinetic calculations}

If the degradation of anthocyanins follows zero-order kinetics, the reaction rate is constant and independent of the concentration. For a first order reaction, the rate of the reaction is directly proportional to the concentration, in agreement with Equation 2, and for a second order reaction, the rate is directly proportional to the square of the concentration, according to Equation 3.

$v=-k C$

$v=-k C^{2}$

where: $k$ - is the reaction rate constant; $C$ - is the concentration of anthocyanins.

In a first order reaction, the anthocyanins degradation rate constant can be calculated using Equation 4.

In $\mathrm{C}_{t}=k t+\operatorname{In} C_{0}$

where: $C_{0}$ - is the initial anthocyanin content; $C_{t}-$ is the anthocyanin content after $t$ minutes.

If the reaction follows first order kinetics, the plot $\ln \left(C_{t} / C_{0}\right)$ against time gives a straight line, in which the slope is $-k$. The calculation of $k$ value allows the determination of the half-life time ( $\left.t^{1 / 2}\right)$ of anthocyanins; in other words, it is the time required to decrease the initial antocyanins concentration by $50 \%$, as shown in Equation 5.

$t_{1 / 2}=k^{-1} \operatorname{In} 0.5$

If the plot of $\ln \left(C_{t} / C_{0}\right)$ against time does not give a straight line, the reaction does not follow first order kinetics; therefore it is necessary to find the reaction order. The next step is to try the second order kinetics. In this case, the plot of $1 / C$ against time gives a straight line. In a second order reaction, the halflife time is inversely proportional to the initial concentration of anthocyanins and can be calculated using Equation 6 .

$t_{1 / 2}=1 / k C_{0}$

The temperature dependence of an Equation 7 can be measured by the activation energy ( $\mathrm{Ea})$, which is calculated using the Arrhenius equation (ATIKINS, 1998):

In $k=\operatorname{In} A-(E a / R T)$

where: $R$ - is the gas constant $\left(8,314 \times 10^{-3} \mathrm{~kJ} \cdot \mathrm{mol}^{-1} \cdot \mathrm{K}^{-1}\right) ; T$ - is the temperature in Kelvin degree; $A$ - is the pre-exponential factor.
Therefore, the activation energy can be calculated plotting $\ln k$ versus $1 / T(\mathrm{~K})$, where the slope is $\mathrm{Ea} / \mathrm{R}$.

Another way to estimate the temperature dependence is to calculate the temperature quotient $\left(Q_{10}\right)$, as shown in Equation 8 . This coefficient gives the rate rise of a reaction when the temperature increases by $10{ }^{\circ} \mathrm{C}$.

$Q_{10}=\left(k_{2} / k_{1}\right)^{10 /\left(T_{2}-T_{1}\right)}$

\section{Results and discussion}

A "coarse" approach to the açaí chain could lead to a false conclusion that the active principles of the drink are preserved when it is maintained at very low temperatures. However, the depulping machines as well as the mixers are not refrigerated. Therefore, the drink is pasteurized some minutes later, i.e, it is submitted to a thermal shock. Lastly, the coarse drink is frozen. Moreover, some final products have even been commercialized at ambient temperature.

\subsection{The temperature and time effect on the anthocyanin content}

The drink is obtained from fruit processing at ambient temperature. Due to the fruit attrition, the temperature of the drink right after using the depulping machine is higher than the ambient temperature. The drink commercialized in local markets is maintained at room temperature, and at home, the consumer stores it in the refrigerator before consumption. After using the depulping machine, the drink to be exported passes through a mixer before pasteurization resulting in a temperature closer to that of the ambient temperature. After pasteurization, the drink is packaged and frozen.

The temperature and time effect on the anthocyanin stability in açai drinks was evaluated at three different temperatures: 0,25 , and $40{ }^{\circ} \mathrm{C}$. At all temperatures tested, the decrease of anthocyanins against time was linear (Figure 1), and it exhibited zero-order kinetics. When stored at $40{ }^{\circ} \mathrm{C}$, the degradation of anthocyanins was 1.8 times faster than at $25^{\circ} \mathrm{C}$ and 15 times faster than at $0{ }^{\circ} \mathrm{C}$. The half-life time $\left(\mathrm{t}_{1 / 2}\right)$ is very sensitive to higher temperatures: at $40^{\circ} \mathrm{C}$ the $t_{1 / 2}$ is 23.9 hours, at $25^{\circ} \mathrm{Ct}_{1 / 2}$ is 42.9 hours, and at $0^{\circ} \mathrm{Ct}_{1 / 2}$ is 372.7 hours (Table 1 ). These values are lower than those found in the literature, studies in which low $\mathrm{pH}$ samples were used.

Pacheco-Palencia, Hawken and Talcott (2007) obtained $\mathrm{t}_{1 / 2}$ values of 4656 and 1399.2 hours in drinks with $\mathrm{pH} 3.5$ and stored at 4 and $20^{\circ} \mathrm{C}$, respectively. De Rosso and Mercadante (2007) obtained $t_{1 / 2}=909$ hours in a commercial drink with $\mathrm{pH} 2.5$ (at $20^{\circ} \mathrm{C}$ ), and Bobbio, Bobbio and Fadelli (2002), using a non-pasteurized drink, found $\mathrm{t}_{1 / 2}=301.2$ hours for drinks with $\mathrm{pH} 2.2$ and $\mathrm{t}_{1 / 2}=182.4$ hours at $\mathrm{pH} 3.0$.

Table 1. Kinetic data of anthocyanins degradation in PLP.

\begin{tabular}{ccc}
\hline $\mathbf{T}\left({ }^{\circ} \mathbf{C}\right)$ & $\mathbf{k} /$ minutes & $\mathbf{t}_{\mathbf{1} / 2}$ (hours) \\
\hline 0 & $0.31 / 10^{4}$ & 372.7 \\
20 & $2.69 / 10^{4}$ & 42.9 \\
40 & $4.84 / 10^{4}$ & 23.9 \\
\hline
\end{tabular}




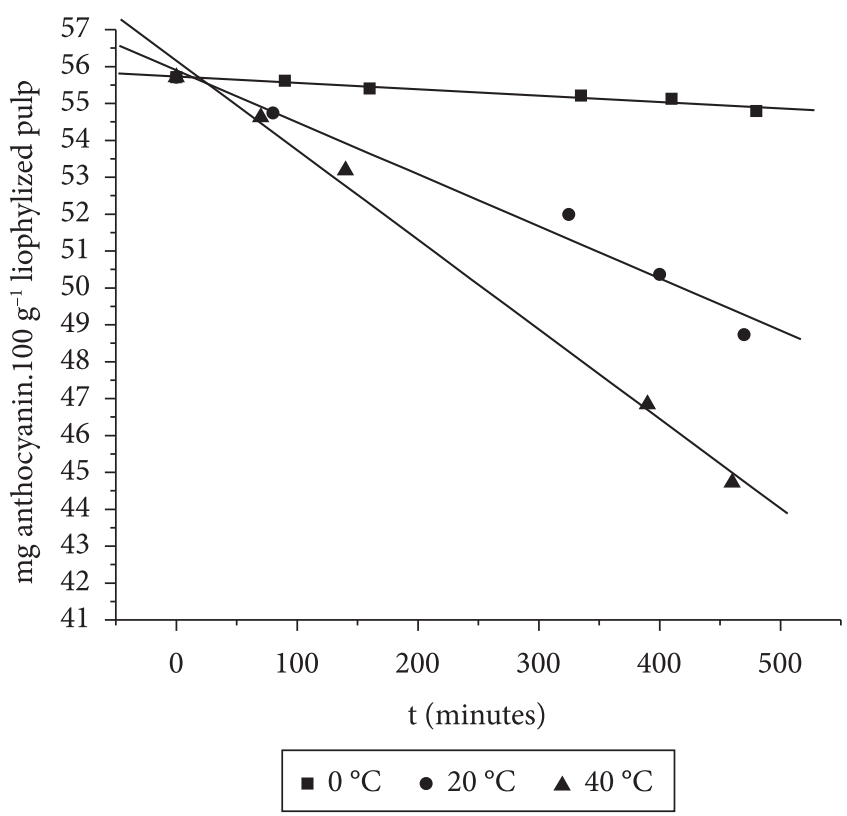

Figure 1. Total anthocyanin mg content of anthocyanins. $100 \mathrm{~g}^{-1}$ of lyophilized açaí and pasteurized açaí pulp at temperatures: $0{ }^{\circ} \mathrm{C}(\mathbf{-})$, $20{ }^{\circ} \mathrm{C}(\bullet)$, and $40{ }^{\circ} \mathrm{C}(\boldsymbol{\Delta})$.

The effect of acidification on the half-life time was demonstrated by Kirca, Ozkan and Cemeroglu (2006) in black carrots stored at $4{ }^{\circ} \mathrm{C}$; they obtained $\mathrm{t}_{1 / 2}=25.1$ hours at $\mathrm{pH} 2.5$, 3.0 and 4.0 , and $\mathrm{t}_{1 / 2}=16.7$ hours at $\mathrm{pH}$ 5.0.

The experimental value obtained for the activation energy (Ea) of anthocyanin degradation in açaí matrix is $49.24 \mathrm{~kJ} \cdot \mathrm{mol}^{-1}$ (in $\mathrm{pH} 5,2)$, lower than the values for blackberry juice $\left(75.50 \mathrm{~kJ} \cdot \mathrm{mol}^{-1}\right)$, pulp (65.06 kJ.mol ${ }^{-1}$ ) (WANG; XU, 2007), and black carrot pulp (63.7 kJ.mol ${ }^{-1}$ ) (KIRCA; OZKAN; CEMEROGLU, 2007); all of them at $4.3 \mathrm{pH}$. The lower values indicate the susceptibility of anthocyanin decay in coarse açaí drinks.

The Temperature Quotient of the drink between zero and $20{ }^{\circ} \mathrm{C}\left(\mathrm{Q}_{20}\right)$ was 2.95 . Between 20 and $40{ }^{\circ} \mathrm{C}$, the $\mathrm{Q}_{20}$ was 2.2 times less (1.34), which indicates the importance of the temperature to the reaction. A previous study presented values for $\mathrm{Q}_{10}(10-20)=1.5$ and $\mathrm{Q}_{10}(20-30)=1.2$ for açaí anthocyanins at pH 3.5 (DEL POZO-INSFRAN; BRENES; TALCOTT, 2004).

\subsection{The effect of pasteurization}

Except for when beverages are destined for the local market, the processing industry pasteurizes the coarse drink. Pasteurization is the exposition of the pulp or juice to temperatures lower than $100^{\circ} \mathrm{C}$ for some seconds, followed by an abrupt decrease to $5^{\circ} \mathrm{C}$. This technique inactivates the enzymes and eliminates the thermal sensitive microorganisms, which extends the products' shelf life. Otherwise, high maximum temperatures may affect the quality of the açaí drink, and low maximum temperatures are therefore useless, thus requiring an adequate selection of the pasteurization parameters (ALENCAR, 2005; RAMASWAMY, 2005; ROGEZ, 2000). In the samples used herein, the initial total anthocyanins found in the pasteurized pulp (NPP-P) and Non-Pasteurized

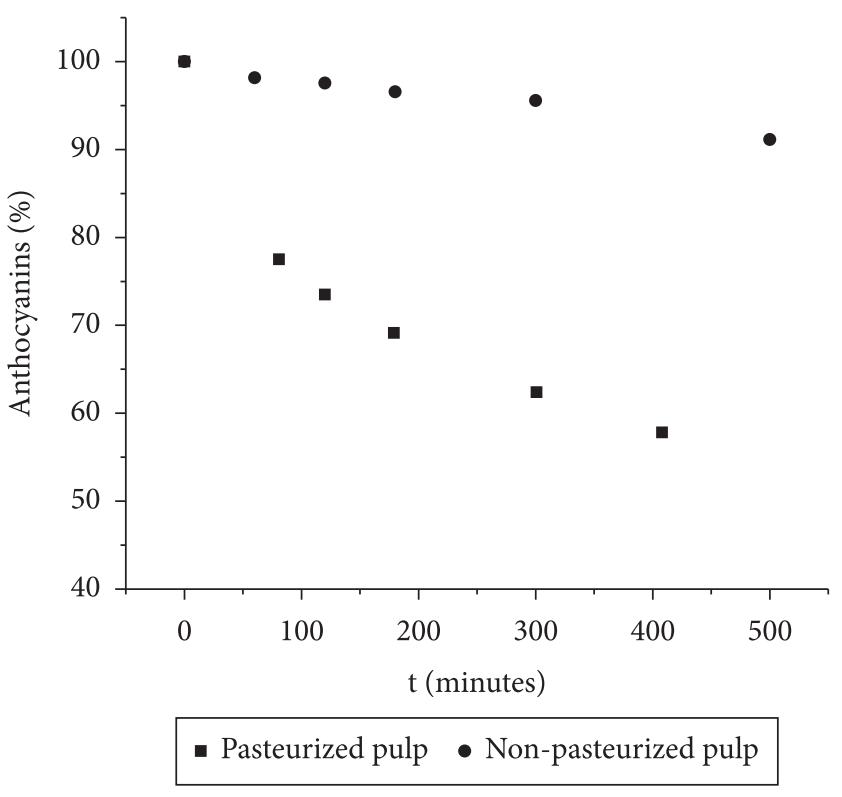

Figure 2. Percentage of anthocyanins against time in non-pasteurized and pasteurized açaí pulp. Pasteurized pulp (•); Non-pasteurized pulp (•).

Pulp (NPP) were 359.92 and $254.02 \mathrm{mg} . \mathrm{L}^{-1}$, respectively. The initial concentration of anthocyanins is higher in NPP-P due to water evaporation during pasteurization and also because the degradation in NPP-P is lower than in NPP during the thawing process.

Some enzymes are temperature resistant, for example peroxidase. They are used as efficiency indicators for thermal treatments and for choosing pasteurization temperatures (SILVA; GIBBS, 2004). In some açaí depulping industries, the pasteurization process occurs under $85^{\circ} \mathrm{C}$ for 30 seconds, with a temperature reduction to $5{ }^{\circ} \mathrm{C}$.

The graph in Figure 2 shows that pasteurization at $90{ }^{\circ} \mathrm{C}$ for 30 seconds significantly reduces the anthocyanin decay in açaí pulp. The pulp was maintained at $40^{\circ} \mathrm{C}$ showing significant differences. At lower storage temperatures, the difference is lower but the conclusion is the same. The anthocyanins of the PP exhibited $8 \%$ of decay during a period of 8.3 hours and NPP of $42 \%$.

Enzymes are natural catalyzers that increase the degradation rate. In PP, the relationship between $\operatorname{lnC}$ and time is linear indicating a first order decay. In NPP, that relationship is exponential. In order to determine whether it is a second order decay, the data was plotted in the form of $1 / \mathrm{C} \times$ time, which indicated a second order decay and $\mathrm{k}=6.47 \times 10^{-6} \mathrm{~L} \cdot \mathrm{mg}^{-1} /$ minutes .

The literature reports the degradation reaction as first order (rate proportional to concentration), and the same was obtained for PP and the second order (rate proportional to the square of concentration) for NPP. The authors observe that the samples used in the present study had natural $\mathrm{pH}$, while in the literature the $\mathrm{pH}$ of the samples was artificially diminished to around 3.5, as expected, hence reducing the anthocyanins decay (BOBBIO; BOBBIO; FADELLI, 2002; PACHECO-PALENCIA; HAWKEN; TALCOTT, 2007). 
The kinetic parameters of the degradation reactions of NPP-P are $\mathrm{k}=1.7210^{-4} /$ minutes and $\mathrm{t}_{1 / 2}=67.28$ hours. In non-pasteurized pulp (NPP), $\mathrm{k}=6.47 \times 10^{-6} \mathrm{~L}^{\mathrm{mg}}{ }^{-1} /$ minutes and $\mathrm{t}_{1 / 2}=10.14$ hours. Therefore, pasteurization increases the half-life time 6.6 times.

\section{Conclusions}

This study shows that temperature influences the storage of açaí pulp since higher temperatures decrease the stability of anthocyanins. The coarse açai drink may present higher values of anthocyanins, and therefore antioxidant activity, if the fruit is processed at low temperature. The study herein also shows that the pasteurization process can improve the preservation of anthocyanins in the pulp. In the pasteurized pulp, the decrease is linear and shows first order kinetics; however, the nonpasteurized pulp showed second order reaction kinetics, which indicates that the concentration of anthocyanins decreases exponentially over time, thus showing that the life time of anthocyanins can be increased by pasteurization. Therefore, pasteurization of the pulp can protect the main compounds that are responsible for the antioxidant properties attributed to açaí pulp.

\section{Acknowledgements}

The authors acknowledge Amazonfrut for their logistic assistance and $\mathrm{CNPq}$ for the financial support.

\section{References}

ALENCAR, A. C. T. Açaí: Novas perspectivas de negócios. Manaus: SEBRAE/AM, 2005. 99 p.

ATIKINS, P. W. Physical chemistry. 6. ed. Oxford: Oxford University Press, 1998. $1014 \mathrm{p}$.

BOBBIO, F. O.; BOBBIO, P. A.; FADELLI, O. S. Stability and Stabilization of the Anthocyanins from Euterpe oleracea Mart. Acta Alimentaria, v. 31, n. 4, p. 371-377, 2002. http://dx.doi.org/10.1556/ AAlim.31.2002.4.6

BRIDLE, P.; TIMBERLAKE, C. F. Anthocyanins as natural food coloursselected aspects. Food Chemistry, v. 58, n. 12, p. 103-109, 1997. http://dx.doi.org/10.1016/S0308-8146(96)00222-1

COSTA, F. A.; ANDRADE, W. D. C.; SILVA, F. C. F. O processamento de frutas no nordeste paraense e região metropolitana de Belém - um arranjo produtivo emergente. Rio de Janeiro: UFRJ, 2004. Disponível em: <www.redesist.ie.ufrj.br>. Acesso em: mar. 2006.

DE ROSSO, V. V.; MERCADANTE, A. Z. Evaluation of colour and stability of anthocyanins from tropical fruits in an isotonic soft drink system. Innovative Food Science \& Emerging Technologies, v. 8, p. 347-352, 2007. http://dx.doi.org/10.1016/j.ifset.2007.03.008

DEL POZO-INSFRAN, D.; BRENES, C. H.; TALCOTT, S. T. Phytochemical composition and pigment stability of acai (Euterpe oleracea Mart. ). Journal of Agricultural and Food Chemistry, v. 52, n. 6, p. 1539-1545, 2004. PMid:15030208. http://dx.doi. org/10.1021/jf035189n

DEL POZO-INSFRAN, D.; TALCOTT, S. T.; PERCIVAL, S. S. Açai (Euterpe oleracea) polyphenolics in their glycoside and aglycone forms induce apoptosis of HL-60 leukemia cells. Journal Agricultural and Food Chemistry, v. 54, n. 4, p. 1222-1229, 2006. PMid:16478240. http://dx.doi.org/10.1021/jf052132n
FULEKI, T.; FRANCIS, F. J. Quantitative methods for anthocyanins, 2. Determination of total anthocyanin and degradation Index for cranberry juice, Journal of Food Science, v. 33, n. 1, p. 78-83, 1968. http://dx.doi.org/10.1111/j.1365-2621.1968.tb00888.x

GALLORI, S. et al. Polyphenolic Constituents of Fruit Pulp of Euterpe oleracea, Mart. (Açai palm). Chromatographia, v. 59, n. 11-12, p. 739-743, 2004.

GIUSTI, M. M; WROLSTAD, R. E. Characterization and Measurement of Anthocyanins by UV-Visible Spectroscopy. In: WROLSTAD, R. E.; SCHWARTZ, S. J. (Eds.). Current Protocols in Food Analytical Chemistry. New York: John Wiley \& Sons, 2001. Unit. F1. 2. 1-13.

IADEROZA, M. et al. Anthocyanins from fruits of açaí (Euterpe oleracea, Mart.) and Juçara (Euterpe edulis, Mart.). Tropical Science, v. 32, p. 41-46, 1992.

KIRCA, A.; OZKAN, M.; CEMEROGLU, B. Stability of black carrot anthocyanins in various fruit juices and nectars. Food Chemistry, v. 97,n. 4, p. 598-605, 2006. http://dx.doi.org/10.1016/j. foodchem.2005.05.036

KIRCA, A.; OZKAN, M.; CEMEROGLU, B. Effects of temperature solid content and $\mathrm{pH}$ on stability of black carrot anthocyanins. Food Chemistry, v. 101, n. 1, p. 212-218, 2007. http://dx.doi. org/10.1016/j.foodchem.2006.01.019

LEE, J.; RENNAKER, C.; WROLSTAD, R. E. Correlation of two anthocyanin quantification methods: HPLC and spectrophotometric methods. Food Chemistry, v. 110, n. 3, p. 782-786, 2008. http:// dx.doi.org/10.1016/j.foodchem.2008.03.010

LEE, J.; DURST, R. W.; WROLSTAD, R. E. Determination of total monomeric anthocyanin pigment content of fruit juices, beverages, natural colorants, and wines by the $\mathrm{pH}$ differential method: collaborative study. Journal of AOAC International, v. 88, n. 5, p. 1269-1278, 2005.

MALACRIDA, C. R.; MOTTA S. Compostos fenólicos totais e antocianinas em suco de uva. Ciência e Tecnologia dos Alimentos, v. 25, n. 2, p. 659-664, 2005.

MARÇO, P. H. et al. Exploratory Analysis of Simultaneous Degradation of Anthocianins in the Calyces of Flowers of de Hibiscus sadbariffa Species by PARAFAC Model. Analytical Sciences, v. 21, n. 12, p. 1523-1527, 2005. http://dx.doi.org/10.2116/analsci.21.1523

MERTENS-TALCOTT, S. U. et al. Pharmacokinetics of anthocyanins and antioxidant effects after the consumption of anthocyanin-rich ac, ai juice and pulp (Euterpe oleracea Mart. ) in human volunteers. Journal of Agricultural and Food Chemistry, v. 56, n. 17, p. 7796-7802, 2008. PMid:18693743. http://dx.doi.org/10.1021/ jf8007037

MOTA, R. V. Caracterização do suco de amora-preta elaborado em extrator caseiro. Ciência e Tecnologia de Alimentos, v. 26 , n. 2, p. 303-308, 2006. http://dx.doi.org/10.1590/S010120612006000200012

OCHOA, M. R. et al. Physical and chemical characteristics of raspberry pulp: Storage effect on composition and color. LebensmittelWissenschaft und- Technologie, v. 32, n. 3, p. 149-153, 1999.

PACHECO-PALENCIA, L. A.; HAWKEN, P.; TALCOTT, S. T. Phytochemical, antioxidant and pigment stability of acai (Euterpe oleracea Mart. ) as affected by clarification, ascorbic acid fortification and storage. Food Research International, v. 40, n. 5, p. 620-628, 2007. http://dx.doi.org/10.1016/j.foodres.2006.11.006

PARÁ (Estado). Secretaria de Estado de Agricultura - SAGRI. Notícias. Disponível em: <http://www.sagri.pa.gov.br>. Acesso em: 4 fev. 2009. 
RAMASWAMY, H. S. Thermal processing of fruits. In: BARRET, D. M.; SMOGYI, L.; RAMASWAMY, H. (Eds.). Processing fruits. 2. ed. CRC Press USA, 2005.

RAPISARDA, P.; FANELLA, F.; MACARONE, E. Reliability of analytical methods for determining anthocyanins in Blood Orange Juices. Journal of Agricultural and Food Chemistry, v. 48, n. 6, p. 2249-2252, 2000. PMid:10888531. http://dx.doi.org/10.1021/ jf991157h

RAYNAL, J.; MOUTOUNET, M. Intervention of phenolic compounds in plum technology. II. Mechanism of anthocyanin degradation. Journal of Agricultural and Food Chemistry, v. 37, n. 4, p. 1051-1053, 1989. http://dx.doi.org/10.1021/jf00088a051

REYES, L. F.; CISNEROS-ZEVALLOS, L. Degradation kinetics and colour of anthocyanins in aqueous extracts of purple- and red-flesh potatoes (Solanum tuberosum L). Food Chemistry, v. 100, n. 3, p. 885-894, 2007. http://dx.doi.org/10.1016/j.foodchem.2005.11.002

RICE-EVANS, C. Screening of phenolics and flavonoids for antioxidant activity. In: PACKER, L.; HIRAMATSU, M.; YOSHIKAWA, T. (Eds.). Antioxidant food supplements in human health. Academic Press, 1999. p. 239-253.

ROCHA, A. P. M. et al. Endothelium-dependent vasodilator effect of Euterpe oleracea Mart. (Acai) extracts in mesenteric vascular bed of the rat. Vascular Pharmacology, v. 46, n. 2, p. 97-104, 2007. PMid:17049314. http://dx.doi.org/10.1016/j.vph.2006.08.411
ROGEZ, H. Açaí: preparo, composição e melhoramento da conservação. Belém: EDUFPA, 2000.

SÁ, M. M.; SERENO, A. M. The kinetics of browning measured during the storage of onion and strawberry. International Journal of food Science and Technology, v. 34, n. 4, p. 343-349, 1999. http://dx.doi. org/10.1046/j.1365-2621.1999.00276.x

SANTANA, A. C. Dinâmica espacial da produção rural do Estado do Pará: referências para o desenvolvimento sustentável. Belém: UFRA, 2006. (Série Acadêmica, n. 02).

SCHAUSS, A. G. et al. Antioxidant capacity and other bioactivities of the freeze-dried Amazonian palm berry, Euterpe oleraceae mart. (açai). Journal of Agricultural and Food Chemistry v. 54, n. 22, p. 8604-8610, 2006. PMid:17061840. http://dx.doi.org/10.1021/ jf0609779

SILVA, F. V. M.; GIBBS, P. Target selection in designing pasteurization processes for shelf-stable high-acid fruit products. Critical Reviews in Food Science and Nutrition, v. 44, n. 5, p. 353-360, 2004. PMid:15540648. http://dx.doi.org/10.1080/10408690490489251

WALKOWIAK-TOMCZAK, D.; CZAPSKI, J. Colour changes of a preparation from red cabbage during storage in a model system. Food Chemistry, v. 104, n. 2, p. 2709-2714, 2007.

WANG, W.; XU, S. Degradation kinetics of anthocyanins in blackberry juice and concentrate. Journal of Food Engineering, v. 82, n. 3, p. 271-275, 2007. http://dx.doi.org/10.1016/j.jfoodeng.2007.01.018 